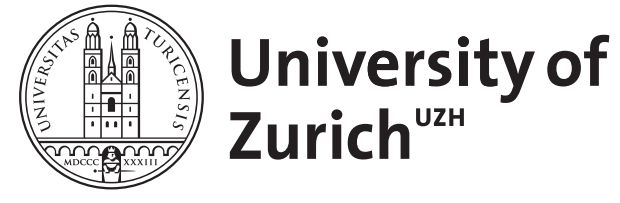

Zurich Open Repository and Archive

University of Zurich

University Library

Strickhofstrasse 39

CH-8057 Zurich

www.zora.uzh.ch

Year: 1976

Restitution and Dissent in the Late Medieval Renewal Movements: the Waldensians, the Hussites and the Bohemian Brethren

\author{
Zeman, J K
}

DOI: https://doi.org/10.1093/jaarel/xliv.1.7

Posted at the Zurich Open Repository and Archive, University of Zurich ZORA URL: https://doi.org/10.5167/uzh-155206

Journal Article

Published Version

Originally published at:

Zeman, J K (1976). Restitution and Dissent in the Late Medieval Renewal Movements: the Waldensians, the Hussites and the Bohemian Brethren. Journal of the American Academy of Religion, XLIV(1):7-28. DOI: https://doi.org/10.1093/jaarel/xliv.1.7 


\title{
Restitution and Dissent in the Late Medieval Renewal Movements: the Waldensians, the Hussites and the Bohemian Brethren
}

\author{
J. K. ZEMAN
}

ๆ[

HE history of the Christian Church and its impact upon Western civilization has often been interpreted as an alternation between periods of recession and resurgence. The motif of renewal thus serves as the organizing principle of the chronological unfolding of the story of the Church. ${ }^{1}$ When expressed in theological terms, it can become a rallying point for advocates of reform, whether in the history of Protestantism, or in the current Catholic aggiornamento: "Insofar as the Church is deformed, she has to be reformed: ecclesia [reformata atque semper] reformanda."2

However, the real dynamic of Christian renewal, whether individual, ecclesiastical or societal, cannot be generated by a mere awareness of the sequence of decay and revival. Rather, it consists in the ever-present tension between those who seek to attain an ideal and those who are willing to compromise. Upon completion of his monumental survey of The Social Teachings of the Christian Churches, Ernst Troeltsch summed up his analysis with the tripartite typology of church, sect and mysticism, and in keeping with his theological orientation, stated:

It [the Kıngdom of God] is an ideal which cannot be realized within this world apart from compromise. Therefore the history of the Christian Ethos becomes the story of a constantly renewed search for this compromise, and of fresh opposition to the spirit of compromise ${ }^{3}$

The Church, as a popular institution, is forced to compromise. The sect, in its desire "to realize the ideal of the Sermon on the Mount in all its purity," 4 opposes

'See, for example, Kenneth Scott Latourette, A History of Christianity (New York Harper and Bros., 1953)

'Hans Kung, The Councll, Reform and Reunion (New York' Sheed and Ward, 1961), p. 35.

${ }^{3}$ Ernst Troeltsch, The Soctal Teachings of the Christian Churches, vol. 2 (London. Allen \& Unwin, 1931), pp 999-1000 For a summary of his typology, see p. 993.

${ }^{4} \mathrm{Ib} 1 \mathrm{~d}, \mathrm{p} 1000 \mathrm{Cf}$ the critical comment on the ethic of the Sermon on the Mount by Matthew Spinka in Church History 12 (1943), p 281 "No wonder that earnest Christians in all ages mistook the ethic of the Kingdom for the binding ethical duties applicable to themselves, and

Jarold Knox Zeman (Dr theol, University of Zurich) studied in Prague, Zurich and Toronto, and is Professor of Church History at Acadia University, Wolfville, N S , Canada $\mathrm{He}$ is the author of several books including The Anabaptists and the Czech Brethren (1969) and has published articles in Central European History, Foundations and Mennonite Quarterly Review A shorter version of this essay was read at the Conference on Restitution, Dissent and Renewal, Pepperdine University, Malıbu, Calıfornaa, June 1975 
accommodation to the world. According to Troeltsch, the adherents of mysticism and spiritualism by and large ignore the issues involved in the compromise.

The observations made by Troeltsch in the concluding chapter of his work provide a fitting introduction to the discussion of the late medieval renewal movements. In his survey of Heresy in the Later Middle Ages, ${ }^{5}$ Gorden Leff has documented the complexities of the search for renewal during the last two centuries of the medieval era, 1250 to 1450 .

He points to the ban on new religious orders issued by the Fourth Lateran Council in 1215 as "a turning point in the development of both the medieval church and heresy." 6 The tension between "the demands of first Christian principles and institutional responsibility" makes renewal movements unavoidable and indispensable to church and society.

The earlier medieval renewal thrusts, from about 900 to 1250 , were furthered primarily by monastic and papal reforms such as the Cluny Movement, and by new religious orders, such as the Cistercians, Franciscans and Dominicans. According to Leff, the decision of the Council in 1215 made inevitable an unprecedented growth of heresies and sects during the period from 1250 to 1450 . The choice between "the broad road" of institutionalized sacramental religion for the majority, and "the narrow road" of monastic ascetıcism for the minority, was no longer available on the same scale. The line between the tolerated heterodoxy within the Church and the persecuted heresy outside the Church had always been a thin one. But now those who sought the ideals of primitive Christianity were increasingly attracted to the clandestine heretıcal or semi-heretical groups which developed outside the Church and in opposition to it.

Leff does not overlook other factors in the popularity of late medieval sects and heresies. The growth, wealth and self-confidence of the urban population, the impact of Eastern ideological influences transmitted by the Crusades, the development of universities, the rise of nationalism: all of these and many other forces contributed to the spread of heretical movements. Yet he concludes:

\footnotetext{
. . heresy was the outlet of a society with no outlets. Their absence made tensions into explosions, and common aspirations the programme of sects Only when the latter became independent churches did heresy lose its impact. Instrumental in the crisis of the later medieval church, it waned with the waning of the church's ecumenicality That was the paradox. Medieval heresy arose from within medieval society and declined with its supersession. It was a Catholic phenomenon concerned with the universal issues confronting a catholic society ?
}

Leff divides the heretical movements into three major categories. The radical

contrary to Jesus' own teaching, strove to live in the intermediate period as if it were the realized Kingdom of God! How much acute spiritual suffering and frustration have resulted from that tragic mistake'm

${ }^{5}$ Gordon Leff, Heresy in the Later Middle Ages, (2 vols.; Manchester Manchester University Press and New York Barnes \& Noble, 1967). For a briefer survey, see Herbert Grundmann, Ketzergeschichte des Mutelalters, 2, pt G of Die Kirche in threr Geschichte, ed Kurt Dietrich Schmidt and Ernst Wolf (Gottıngen. Vandenhoeck \& Ruprecht, 1963).

${ }^{6}$ Leff, Heresy in the Later Middle Ages, p. 15 Our summary of Leff's analysis is based on his Prologue, pp $1-47$

'Ibid , p 47 Leff's statement about the dissipation of later medieval heresies in the Protestant Reformation is contradicted, at least in part, by evidence of continuity of some heresies, e $\mathrm{g}$. the Free Spirit See Claus-Peter Clasen, "Medieval Heresies in the Reformation," Church History, 32 (1963), pp 392-414 
wing of the Franciscan order (the Spirituals and the Fratıcelli), the Beguins, the Joachimites and others are grouped together under the theme of "poverty and prophecy." Eckhartian mysticism and the heresy of the Free Spirit are treated under the theme "union with God." Finally, the Cathars, Waldensians, Flagellants, Lollards and the Hussites constitute the third stream designated as "the true Church."

The classification of particular groups under one of the three categories may be questioned. However, the themes as such can be endorsed as helpful indicators of the major areas of concern for renewal during the period under study. Above all, they show the nature of late medieval dissent as a protest against and a complement for the deficiencies of the official Church. The ideal of apostolic poverty was held up as a mirror to a Church which had become the wealthiest and the most oppressive collector of taxes and tariffs from birth to death. The expectation of an imminent return of Christ served as a rebuke to a Church domiciled and comfortable in this passing world. For most medieval sectarians, the return to the true apostolic Church implied a condemnation and rejection of the fallen post-Constantinian Church.

There is a serious omission in Leff's typology. One of the main emphases, if not the fundamental emphasis in the early Waldensian, and then in the Lollard and Hussite Movements was a sense of apostolic mission expressed through the preaching of the message of the Bible in the vernacular. This thrust can be appreciated only when it is understood as a reaction to the neglect of preaching in the parish churches and to their predominantly sacramental ministries.

The dialectical tension and ideological interaction between Church and sect, establishment and dissent, cannot be stressed enough. "The ideal of the radical sects was never developed out of a purely inward dialectic of Christian thought."8 Medieval religious dissent as much a reaction to the conditions and needs in Church and society as it was a response to the message of the Scriptures and of the Spırit.

Keeping in mind these general observations on the nature of renewal and dissent, we now turn to our specific inquiry. First, we shall delineate its limits. We have narrowed the chronological focus of the present study to a century and a half, from 1378 to 1525 . References to earlier trends will of course be included.

The choice of destınation is obvious. The recorded rise of Anabaptism in 1525 marks the transition from late medieval dissent to restitutionism within the Protestant Reformation. It can also serve as the terminal point for the creative period in the theology and life of the Unity of Brethren in Bohemia and Moravia By 1525 Luke of Prague, the foremost theologian of the Brethren, had completed his "restitutionist" theological system. During the remaining three years of his life, Luke entered into dialogue with the Zwinglian, Spiritualist and Anabaptist ideas which influenced limited circles within the Unity. ${ }^{9}$ But his own position was not affected.

The selection of the year 1378 as the point of departure should be equally selfevident. "No part of Europe escaped the shock of the so-called Papal Schism in 1378." 10 Many ideological influences had been undermining the authority of the

${ }^{8}$ Troeltsch, The Social Teachings of the Christian Churches, vol 2, p 817

'See the analysis of this confrontation in J K Zeman, The Anabaptists and the Czech Brethren in Moravia 1526-I628 (The Hague-Paris Mouton, 1969), particularly chs 2 and 4

${ }^{10}$ Frantısek Graus, "The Crisis of the Middle Ages and the Hussites," in Steven E Ozment 
Church and the Pope. But the Schism dealt a death blow to the whole system of sacramental security which was at the center of life for medieval Christians. Which Pope was the true Vicar of Christ and which priests could be trusted for an efficacious administration of sacramental rites?

Thus the beginning of Papal Schism signalled the final stage not only in the crisis of papal and ecclesiastical authority but also in the collapse of the foundations of medieval spirituality. "The Middle Ages was primarıly concerned with the guarantee of security the Church offered to believers, and only secondarily with doctrine." 11 The Schism posed the question as to the identity of the true Church with extreme urgency. Thus the concept of the Church became the central concern both among the late Waldensians and in Wycliffite circles, and subsequently in the Hussite Reformation.

The year 1378 must also be regarded as a watershed in Bohemian and Central European history. The reign of Emperor Charles IV (1346-1378) was characterized by a political order with centralized monarchical power, by unwavering support of the Church and its orthodoxy, and by patronage of learning and arts. His death was followed by decades of struggle for power between his weak successor Wenceslas IV and the powerful Bohemian nobility, a struggle aggravated by religious, national and class tensions among the populace at large. The outbreak of the Hussite Revolution in 1419 was the ultimate outcome of the protracted crisis. ${ }^{12}$

The chronological termini of our inquiry are related to the geographical and topical delimitation. The confluence of the Waldensian and Wycliffite ideologies in pre-Hussite and Hussite Bohemia, enriched by other influences such as Pikartism and the Free Spirit, provides a most fruitful case study of late medieval reformism and restitutionism. Our main focus will thus be on Central Europe. The earlier Southern phase of the Waldensian Movement in France and Italy will be mentioned only marginally. Its later phase, North of the Alps and mainly Germanspeaking, displays distinctive marks so as to merit a separate treatment, particularly since the remnants of the underground movement, decimated by the Inquisition, found a new lease on life under the impact of Hussitism. ${ }^{13}$

\section{Pietism and Reform Preaching in Pre-Hussite Bohemia}

Prague, the capital of the Holy Roman Empire from 1346 to 1400 and the first city North of the Alps to boast a university (1348), became an important meetings

(ed.), The Reformation in Medieval Perspective (Chicago Quadrangle Books, 1971), p 88 This perceptive essay by the Czech medievalist should be read as an introduction to our inquiry We disagree with his final negative evaluation of the Hussite solution to the medieval crisis (pp 100ff ) Cf the effects of the Great Schism on the Czech Reformer Matthew of Janov as reported by Leff, Heresy in the Later Middle Ages, p 615

"Graus, "The Crisis of the Middle Ages," p 98

${ }^{12}$ For a picture of this period, see Kamil Krofta, "Bohemia in the Fourteenth Century," in The Cambridge Medieval History, 7 (Cambridge, 1932), pp 155-82, and "Bohemia in the Fifteenth Century," ıbıd , 8 (Cambridge, 1936), pp 65-115, S. Harison Thomson, Czechoslovakia in European History, rev ed (Princeton Princeton University Press, 1953); Howard Kamınsky, A History of the Hussite Revolutıon (Berkeley-Los Angeles University of California Press, 1967), R R Betts, Essays in Czech History (The Athlone Press, University of London, 1969), and Ruben E Weltsch, Archbishop John of Jenstein 1348-1400 (The Hague Mouton, 1968)

${ }^{13}$ Donald F Durnbaugh deliberately chose the Waldensians and the Unity of Brethren as the point of departure for his review of the Believers' Church Movement in history See his The 
place of ideas and influences. Cola di Rienzo visited the city and the imperial court in the middle of the century. Petrarca had personal friends among the high officials of Church and state in Prague. The international community attached to the court and university included supporters of scholastic nominalism and early humanism, and adherents of devotia moderna. ${ }^{14}$ Among them was the young Dutch mystic Gerard Groot, a student in Prague around 1370.

Similar in its emphasis on inward piety and morality but independent in its ongins and goals was a domestic reform movement of "pietism." The leading representatives were Thomas Štitný (d. 1400) and Matthew of Janov (d. 1393), both prolific writers. They were influenced by their older contemporary, a zealous preacher, Milí̌ of Kroměřž, desıgnated by modern historıans as "the Father of the Hussite Reformation." His apocalyptic messages about the coming of the Antichrist - sometımes applied to false Christians in general and at other times dDected unmistakably against the Papacy - led to repeated charges of heresy against him. He proved his innocence but died in Avignon in 1374 while answering a new summons by the Pope. Milí, who preached mostly in Czech, was indebted to an earlier German reform preacher, an Austrian-born Augustinian monk, Conrad of Waldhausen (Waldhauser). He came to Prague in 1360, won the Emperor's support and remained in Bohemia until his death in 1369.15

The tradition of public reformist preaching in the language of the people, Czech and German, was thus firmly established in Prague and other Bohemian and Moravian urban centers for at least a generation prior to the career of John Hus. Milic also initiated preaching of the Gospel by laymen, and in 1367 proposed to the Pope a universal preaching mission (as a fulfillment of Christ's words recorded in Matthew 24:14 and Mark 16:15).

The legacy of Milic was expressed in a permanent form in 1391 when two burghers erected the Bethlehem Chapel in Prague It was the first church building designated exclusively for preaching (In the vernacular) without the sacramental ministries of a typical parish church. In 1402, the pulpit of the Bethlehem Chapel became one of the two platforms for John Hus' reform crusade. The other one was the University. It should be noted that Hus' preaching did not mark the beginnıng of a popular reform movement but rather a climax to a long tradition. In that sense, one might endorse the statement made by Amedeo Molnár: "In the perspective of the history of ideas, the Hussite Movement preceded Hus."16

Believers' Church The History and Character of Radical Protestantism (New York: Macmillan, 1968), pp $37 \mathrm{ff}$

${ }^{14}$ See the important study by Eduard Winter, Fruhhumanismus Seine Entwicklung in Bohmen und deren europaische Bedeutung fur die Kirchenreformbestrebungen im 14 Jahrhundert (Berlın Akademie-Verlag, 1964).

${ }^{15}$ For further details, see Thomson, Czechoslovakia in European History, ch 5, and Leff, Heresy in the Later Middle Ages, ch 9 The bibliographical references for the Hussite Movement will be limited to works in English wherever possible For further readıng consult $\mathbf{J} \mathrm{K}$ Zeman, The Hussite Movement and the Czech Reformation 1350-1650 A Bubliographical Gude and Finding List for Situdies in America (forthcomıng) and the extensive biblography in Kamınsky, A History of the Husstie Revolution, pp 551-67

${ }^{16}$ Amedeo Molnár, "Odkazy a podnéty," Kostnické jiskry, 57, no 4 (Prague, January 26, 1972) Cf Leff, Heresy in the Later Middle Ages, p 607, and the statement by Paul de Vooght "Toutes les ıdées, propagées plus tard par Jean Hus et le hussitisme, les Frêres bohêmes et les utraquistes, retrouvent en germe chez Milic " L'hérésıe de Jean Huss (Louvaın: Bıblıothèque de la Revue d'histoıre ecclésıastıque, facs 34, 1960), p 8 See also the discussion by Amedeo Molnár in 
The central role which public preaching played in the preparation of the Hussite Reformation should not obscure the equally strong emphasis on frequent communion as a means of grace. In his Regulae veteris et novi testamenti ${ }^{17}$ Matthew of Janov extolled the Bible as his friend and bride, indeed mother, from the time of his youth, and as the supreme rule of faith. With even greater fervor, he pleaded for daily communion by priests and laymen alike. The eucharist enabled the believer to renew his union with Christ through sacramental participation in his nature.

The Bible and the eucharist were the twin foundations of Janov's piety and theology. They remained the two foci of the Hussite Movement. Eventually, the chalice, restored to the laity in October 1414 (communion sub utraque specie) was to become the hallmark of Hussite unity. The chalice was emblazoned on the shields of the "Warriors of God" as they went to battle. It also supplied a name for the new national Church and its members, the Utraquists or Calixtınes.

\section{The WaLdensians}

The Hussite Movement of the early fifteenth century was enriched and strengthened by two international influences, Waldensian and Wycliffite.

The Waldensian thrust in Bohemia was initially restricted to the rural areas in the South and confined to German settlers. The presence of the Waldensian heretics is confirmed by records of the Inquisition from the early fourteenth century on. The Waldensians survived only as isolated groups of secret believers. Their perseverance was nourished, in most cases, by a vague consciousness of a legendary succession of dissenters, from the time of Peter Valdes, who was regarded as a contemporary of Emperor Constantine and Pope Sylvester in the fourth century.

Occasionally, the local fellowshıps were visited by itinerant missionaries from Germany whose main task was to admonish the believers and to hear their confession (in the sacramental sense). The witness and life-style of the Germanspeaking Waldensian communities in the fourteenth century stood in sharp contrast to the missionary thrust of the original Waldenses in France and Italy. ${ }^{18}$

The early followers of Valdes in the late twelfth century were inspired by the model of apostolic ministry in the New Testament (Matthew 10 and Luke 10) and

his important article "L'évolution de la théologie hussite," Revue d'historre et de philosophie rélıgıeuses 43 (Strasbourg, 1963), pp 136ff

"Matthiae de Janov, Regulae veterıs et novi testamenn, eds V Kybal and O. Odložllík, (5 vols.; Prague, 1908-1926). We follow the summary in Leff, Heresy in the Later Middle Ages, pp $613 \mathrm{ff} \mathrm{Cf}$ V. Kybal, "Etude sur les origines du mouvement hussite en Bohème: Matthas de Janov," Revue historique, 103 (1910), pp. 1-31; V Novotný, "Les orıgines du mouvement hussite en Bohême," Revue de l'histoire des relıgıons, 89 (1924), pp. 77-90, and Jana Nechutová, "M Maté z z Janova v odborné literatưe," Studıa Minora Facultatıs Phılosophicae Universitatis Brunensis 21 (Brno, 1972), pp. 119-32

18 In our interpretation of the Waldensian movement we follow the main conclusions of Amedeo Molnár in his recent comprehensıve history, Valdensti Evropský rozmér jejıch vzdoru (Prague Kalıch, 1973; also publıshed in French, Les Vaudoss au Moyen Age, Torıno. Claudiana, 1974), with extensive bibliography See also Leff, Heresy in the Middle Ages, pp 452-83, and Rudolf Holınka, Sekıáłsıvi v Cechách píed revoluci husısskou (Sbornik Unıversıty Komenského 6. No 52, Bratislava, 1929) In an important new work, Die Anfange einer standigen Inquisition in Bohmen (Berlın-New York- Walter de Gruyter, 1975), Alexander Patschovsky questions the evidence for the presence of the Waldensian heretics in Bohemia during the first half of the fourteenth century 
embarked upon public preaching missions Their appeal for return to primitive Christian poverty and non-violence was addressed to the whole of Christendom within their reach. Through the two hundred years of persecution, the little groups gradually gave up a public mission directed to the Universal Church and instead withdrew into clandestine sectarianism often disguised by participation in the sacraments in local Catholıc parishes.

The Waldensian remnant survived. In the 1420 s and 1430 s the bold Hussite Revolution in Bohemia, and its echoes in Germany, rekindled the original vision in the scattered communities. In return, the Hussites, and particularly their radical wing, the Taborites, were helped by the German Waldensian messengers to keep alive the hope for a universal Reformation. The contacts with the Waldensians enabled the first generation Hussites to resist the temptation of a purely national Reformation, fostered by strong anti-German feelings.

Several Waldensian leaders, in particular Peter and Nicholas of Dresden, John of Drändorf, Peter Turnow and Friedrich Reiser, contributed to the evolution of Taborite theology. ${ }^{19}$ The extensive Hussite propaganda in Germany and other lands has been described as a sort of Hussite-Waldensian "international."20

The ecclesiological dimension of the Waldensian dissent is difficult to assess. Some interpreters of the preserved in-group and out-group sources maintain that "the Waldensians set themselves up as an alternative church," "an independent church" with its own ritual and ministry (barbes, perfecti). ${ }^{21}$ Others claim that the movement up to 1450 , never developed into a fully separate church. 22

The inner circle of the brotherhood originally consisted of itinerant preachers who sought to fulfill the dominical commission and imitate the apostolic example in such literal details as wearing sandals (hence nicknamed sabatati or insabatati). They were usually known as the masters or "the perfect ones." Under the pressure of persecution their main role changed to confessors. In some areas they appear to have observed the three traditional orders of ministry unless such reports merely reflect inquisitorial interpretation.

The outer circle included "believers," "disciples," "friends" and followers with varying degrees of unitiation and commitment. Whereas the masters separated themselves from the Catholic Church and developed a sense of belonging to a "missionary society," the average "believer," particularly under the stress of persecution, maintained an ambivalent dual relationship, to his secret group on the one hand and to the Catholic parish on the other. The parocial network with its focus on the detection of heresy appears to have prevented a consistent development of separate Waldensian congregations.

\section{The INFLUENCE OF WyCLIF}

The influence of Wyclif was facilitated by the relations between the royal courts of Bohemia and England. In 1382, Anna, daughter of Emperor Charles IV,

\footnotetext{
19See Howard Kamınsky, "Nicholas of Dresden and the Dresden School in Hussite Prague," Introduction to Master Nicholas of Dresden, The Old Color and the New, ed H Kamınsky et al, Transacions of the American Philosophical Society, N S, 55, pt 1 (Philadelphia, 1965), and Jana Nechutová, Misto Mikuláse z Drázd'an v raném reformaźnim myšleni (Rozpravy CSAV, 77, no 16, Prague Academia, 1967), with German summary

${ }^{20}$ Molnár, Valdenšti, p. 218. Cf F. M Bartoš, Hustıství a cizına (Prague Cin, 1931) and Josef Macek (ed), Mezinárodni ohlas husttstvi (Prague CSAV, 1958).

${ }^{21}$ Leff, Heresy in the Middle Ages, pp 457, 463.

${ }^{22}$ Molnár, Valdenšti, pp. IS9ff Cf. also Molnár's rejection of Leff's interpretation in Theologická priloha K'est' anské revue (Prague), 1968, p 117
} 
was marned to Richard II. In due course, student exchange developed between Oxford and Prague. Before the end of the century, Wyclif's writings were brought to Prague and evoked an immediate response.

The extent of Wyclif's influence on Hus and the Hussite Movement has been the subject of a long controversy complicated by the ethnic loyalites of Czech and German historians ${ }^{23}$ The national aspect of the issue emerged already in the days of Hus. The endorsement or rejection of Wycluf's teachings coincided, on the whole, with the national division between the Czech minority and German majority at the University of Prague. The reversal in the control of the University in favor of the Czech masters (by a royal decree in 1409) led to a mass exodus of the German academic community to Leipzig and to the founding of a new university there. In Prague, the event was celebrated as the victory of the reform party and effectively accelerated the progress of the Reformation under the leadership of Hus

The main contribution of Wyclif's writıngs to the Hussite cause - Wyclif himself had died in 1384 - was to furnish more sophisticated theological concepts for the reformist aspirations developed by the native leaders, from Milic to Hus. At the risk of oversimplification, the main tenets may be summed up as follows. ${ }^{24}$

The Universal Church was defined as the fellowship of the elect (predestined) rather than a body coterminous with the institutional Church of Rome. Christ, rather than the Pope, was declared the true Head of the Church. The Law of Christ (lex Christi) was endorsed as the absolute law taking precedence over the relative and often corrupt ecclesiastical and civil laws. In an extended sense, the Law of Christ became synonymous with the authority of the Scriptures in theological and moral issues. The laity was assigned a crucial role in the life of the Church. The important distinction, introduced by Marsilıus of Padua, between dominium and usus, was applied to church properties. It implied the right of the state to confiscate church properties when abused. The rejection of the wealth of the Church called for the restoration of the priesthood to apostolic poverty. In eucharistic theology, Wyclif replaced the doctrine of transubstantiation with the concept of remanence (consubstantiation). In contrast to the strong apocalyptic note in the Czech reformist tradition, eschatology remaıned margınal in Wyclif's thought. ${ }^{25}$

To summarize: the crucial formative influences in the emerging Hussite Movement in the early fifteenth century included (1) the vigorous domestic tradition of reformist preaching - related to early humanism - in which the abuses of the Church and society were exposed and attacked; (2) the supportive literary tradition in the vernacular, with a focus on personal piety and frequent

${ }^{23}$ See the most recent evaluation of the debate, with critical review of literature, in Miloslav Kañák, John Viklef Żvot a dilo anglıckého Husova pr̈edchridce (Prague Blahoslav, 1973), pp 64-99 Cf R R Betts, Essays in Czech History, pp 186ff, Howard Kamınsky, "Wyclif ism as Ideology of Revolution," Church History 32 (1963), pp 57-74, Matthew Spinka, John Hus' Concept of the Church (Princeton Princeton University Press, 1966)

${ }^{24} \mathrm{Cf}$ Leff, Heresv in the Middle Ages, pp 494-559, Troeltsch, The Social Teachings, pp 358 ff, and Gordon Leff, "The Apostolic Ideal Later Medieval Ecclesiology," Journal of Theological Siudies, N S , 18 (1967), pp 58-82

${ }^{23} \mathrm{Cf}$ Amedeo Molnár. "Eschatologıcká naděje české reformace" in Od reformace $k$ zirrk $k u$ (Prague Kalıch, 1956), pp I3ff and his "L'évolution de la théologıe hussıte" (cited in footnote 16) 
communion; (3) the Waldensian influence; and (4) the impact of Wycliffite theology in academic and clerical circles.

It will be obvious that these streams of influence were in some respects complementary and in other points mutually contradictory. Under the pressure of the politıcal, social and economic conditions which prevalled in Bohemia during the second decade of the fifteenth century, they worked together in producing "the first great European revolution." 26

\section{The Moderate Hussite Reformism: Utraquism}

We shall bypass the familiar story of the career of John Hus and the unfinished debate on the originality of his thought in relation to the theology of Wyclif. ${ }^{27}$ Nor shall we recount the heroic events of the Hussite Revolution and Wars and the complex domestic and international forces at work during the two decades, 1415 to $1436 .{ }^{28}$ Our brief observations will be devoted to the process of radicalization in the Hussite concept of reform and dissent.

In a recent perceptive article on the relationshıp between Hus and Luther, Scott H. Hendrix asks: "What was Hus after: a reform of morals or a reformation of the church?"29 Obviously both. Hendrix then explores the potentially schismatic effect of Wyclif's and Hus' concept of the Church as the congregatio praedestinatorum. Since only the elect belong to the true Church of Christ, how could it be identified with the institutional Roman Church, particularly if the latter is coterminous with the whole society and displays many marks of betrayal of Christ?

Against the papal condemnation, Hus had appealed to Christ as the supreme Judge and Head of the Church. Consistent reasoning might have led the Bohemian Reformer to advocate the formation of a Church separate from the Roman jurisdiction. However, in Hus' view, "one can never be certain that one is predestined. Therefore, one is driven to the means of grace to obtain the cartlas which makes predestination efficacious. . . The society of the predestined could not survive without the traditional food of sacramental grace." 30

Hendrix rightly underscores "the intımate relationship between ecclesıology and soteriology which existed in the medieval tradition, ${ }^{n 1}$ and remained central in

${ }^{26}$ Charles H George (ed ), Revolution Five Centuries of Europe in Conflict (New York Dell Publıshıng Co, 1962), p 37, and Frederıck G Heymann, George of Bohemia King of Heretics (Princeton Princeton University Press, 1965), p vil and 600

${ }^{27}$ Leff's summary (Heresy in the Middle Ages, p 619) is worth noting "Accordingly, Hus had many forerunners [1n the domestıc reform movement in Bohemia] He was first and foremost their successor and only secondarily Wyclif's disciple what he added to their achievement was not new doctrine, either on his own or Wyclif's account, but the courage of the convictions which he had gained from them He translated these from being the property of a small band into becoming the standard of a national movement "

${ }^{28} \mathrm{See}$, among others, Frederick G Heymann, John Žizka and the Hussite Revolution (Princeton Princeton University Press, 1955), Howard Kaminsky, A History of the Hussite Revoluiton, and a Marxist interpretation by Josef Macek, The Hussite Movement in Bohemia (2nd ed, Prague Orbis, 1958)

${ }^{29}$ Scott H Hendrix, "We Are All Hussites"? Hus and Luther Revisited," Archive for Reformation History 65 (1974), p 149

30Ibıd, pp 156-57 Cf Ernst Werner, Der Kirchenbegriff bei Jan Hus, Jakoubek von Mies. Jan Zelivsky und den linken Tabortten (Berlın, 1967)

'Ibid, p 159 
the theology of sixteenth-century Reformers. Hus and his followers in the mainstream of the Hussite Movement, never resolved their ecclesiological dilemma pror to their contacts with the Lutheran Reformation. Many of them condemned the Roman Church as the apostate Church of Antichrist. Yet the efficacy of the sacraments administered by the Hussite priests, and therefore salvation itself, depended upon ordination in the apostolic succession. For a whole century, the Utraquist Church suffered from a chronic lack of priests since ordination could only be procured secretly and often under false pretenses from Catholic bishops in other countries. During the negotiations with the Council of Basel in 1435, John of Rokycana (d. 1471) was elected Archbishop by the diet. But the expected confirmation by the Pope never came and thus Rokycana lacked ordination powers.

The national Utraquist Church anticipated most of the characteristics of the Magisterial Reformations in the sixteenth century. The control of the Church quickly passed from the episcopal see to the Bohemian diet. Sometimes it went to city councils, especially in Prague, and during the "Podebrady era," into the hands of the "Hussite King," George (d. 1471).

In September 1415 the Bohemian diet recognized the right of the University to arbitrate doctrinal issues according to the norm of Scriptures. The decision implied the transfer of the magisterium (the teaching office of the Church) from the Pope and General Council to the University. When the University suffered from decay in subsequent decades, theological and administrative issues were settled by convocations of clergy, or by the Utraquist consistory in Prague which replaced the episcopal authority. King George often summoned convocations of clergy and in other ways anticipated the Erastian policies of the following century.

With the sole exception of the sacramental power of ordination - which of course was indispensable to the life of the Church - the Utraquist Church functioned as a schismatic national Church. Apart from the cup for the laity and the use of the vernacular in worshıp, the degree of deviation from Roman doctrine varied greatly With considerable justification, one might describe the Utraquist Church as a proto-Anglican Church, with uniformity in worship and breadth in doctrine. ${ }^{32}$ The Calixtines took over the vast majority of the parish network in Bohemia and Moravia. With the passing of the revolutionary zeal they reinstated the traditional collection of tithes and other dues.

The small Roman Catholic Church remained fully obedient to Rome It controlled its network of parishes, some of them concentrated in areas unaffected by Hussitism, others located next to the Utraquist parish churches. The two "popular" Churches (Volkskirchen) lived side by side and gradually accepted religious dualism and mutual toleration. The Religıous Peace of Kutná Hora (1485) guaranteed to individual persons of all classes, including the peasants, freedom to choose between the two communions. The principle of ecclesiastical dualism, soon to become pluralism, was recognized for the first time in modern European history. ${ }^{33}$

${ }^{32} \mathrm{Cf}$ Enrico C S Molnar, "The Catholicity of the Utraquist Church of Bohemia," Anglican Theological Review 41 (1959), pp 260-70 See also the excellent essays by F G Heymann, "John Rokycana - Church Reformer between Hus and Luther," Church History 28 (1959), pp 240-80, and "The Hussite-Utraquist Church in the Fifteenth and Sixteenth Centuries," Archive for Reformation History 52 (1961), pp I-16

33J K Zeman, "The Rise of Religious Liberty in the Czech Reformation," Central European Histori 6 (Atlanta. Ga, 1973), pp 137ff 
We have reviewed the final ecclesiological outcome of the moderate and conservative Hussite Movement prior to its encounter with the Lutheran Reformation. We must now return to the beginnıngs of the Movement to consider its more radical wing.

\section{The Radical Hussite Dissent: The Taborites}

A revolution resembles an explosion. The whole is fragmented into small parts which are dispersed in all directions. Howard Kaminsky has aptly described the situation in Prague and Bohemia after 1414 "as a movement for reform, which then became a revolt both then became wider and deeper, the reform passing into reformation, the revolt into revolution." 34

Under the threat of interdict in the fall of 1412, Hus left Prague for the Bohemian countrysıde. What initially appeared to be his retreat and triumph for the Church authorities, turned out to be a signal for the victorious march of revolutionary forces Instead of reaching a limited audience in the Bethlehem Chapel or at the University, Hus now preached to large outdoor assemblies of common people. After his death in Constance (1415), the mass meetings (tábory, camps) continued and spread to other parts of Bohemia. Popular expectations were aroused; religious enthusiasm soon bordered on apocalyptic hysteria ${ }^{35}$

A careful examination of the records has led several modern historians to divide the Hussite radicalism from 1415 to 1436 into three phases. ${ }^{36}$

From about 1415 to 1419 , the popular preachers at open a1r assemblies advocated ideals similar to the Waldensian non-violent dissent. They repudiated the wealth and power of the Church and pleaded for a return to the poverty and humility of primitive Christianity, particularly as they saw it embodied in the Sermon on the Mount. It remains a matter of hypothesis whether the Hussite radicals owed their vision to the influence of the Waldensian conventicles in Southern Bohemıa and the Waldensian messengers from Germany, or whether they developed their program independently, through the reading of the New Testament. It is equally difficult to determine whether their restitutionist dissent led to the formation of separate local congregations during this early phase.

In 1419, the radical circles in the countryside, and to a lesser extent in Prague, turned to adventist expectation of the imminent return of Christ. The date was set for February 1420 and the saints were encouraged to escape to one of five designated cities Anywhere else the ungodly would be annihilated.

The eschatological hope had been one of the central motifs in the Czech reform

${ }^{34}$ Kaminsky, A History of the Hussite Revolution, p 3 See also pp $481 \mathrm{ff}$

${ }^{35}$ Hussite camps (tábory) with their fervent preachıng and singing bear a strikıng resemblance to the Methodist open air assemblies in Wesleyan England or to the camp meetings during the Amencan revivals There is, of course, a fundamental difference in theological outlook

${ }^{36}$ We follow the thorough studies and interpretation of Kaminsky, A History of the Hussue Revolution, chaps IV-X, and his earher articles, "Chiliasm and the Hussite Revolution," Church History 26 (1957), pp 43-71, "Hussite Radicalısm and the Origins of Tabor 1415-1418," Medievalia et Humanistica 10 (1956), pp 102-30, "The Free Spirit in the Hussite Revolution" in Millennial Dreams in Action, ed Sylvia L Thrupp (New York Schocken Books, 1970), pp 16686, "The Religion of Hussite Tabor" in The Czechoslovak Coniribution to World Culture, ed Miloslav Rechcigl, Jr (The Hague-London-Pans Mouton, 1964), pp 210-23 Cf also Ernst Werner, "Popular Ideologies in Late Medieval Europe Taborite Chiliasm and Its Antecedents," Comparative Studies in Society and History 2 (1960), pp 344-63 
movement from the days of Milic and at times included the identification of Antichrists and fixing of dates. It might be assumed, therefore, that the original outburst of apocalyptic enthusiasm in 1419 was a continuation and radicalization of an old tradition.

However, the chiliastic thrust soon was accompanied by the heresy of the Free Spırit and "Pikartism" The latter ideology taught a purely commemorative view of the eucharist. Others rejected traditional communion altogether and replaced it by love feasts held in homes and presided over by laymen

A new city, Tabor, named after a mountain in the Bible, was founded in the midst of this chiliastic and spiritualist explosion in the spring of 1420. Radicals of all sorts flocked into it and for a while established a communal society. It bore every resemblance to the "New Jerusalem" in Munster a little more than a century later Meanwhile, a popular revolution was under way in Prague. The death of King Wenceslas and the rejection of his brother Sigismund's legitimate claim upon the Bohemian throne led to the first crusade against the Hussites in 1420.

The soberıng prospects of a military invasion brought to an abrupt end the second phase of Hussite (mainly Taborite) radicalism. The government of the city of Tabor, and of other urban centers of radicalısm, was reorganized to meet the war emergency. The chiliastic and spiritualist extremists were expelled, and the libertınian Adamites, who had established "nudist colonies" in keeping with their ultimate restorationism of paradisaic life-style, were exterminated by the commander of the Hussite Warriors of God, John Žižka. ${ }^{37}$

The third stage of Taborite radicalism was described by Kamınsky as follows:

[The early pacifistic and chiliastıc] sectarianism was rejected in favor of the standard medieval doctrine, derived from Wyclif and shared by the Prague masters: that the Church miltant was the social order, with secular power exercısing the Christian function of defending God's Law by force. This concept of a Christian society was purely medieval, and the contending parties in Bohemia differed only in regard to the framework withın which it would be realızed for the Romanists it was Europe, for the Praguers the nation, for the Taborites the congregational community 38

A conservative Hussite opponent of the Taborites reported. "They regard themselves as the Holy Universal Church of all Christendom." 39

Tabor attempted to revive the Primitive Church by strict obedience to its Law and by cuttıng away every doctrine and practice that stemmed from post-primitive times, thus Tabor became the Primitive Church, in more than a figurative sense 40

In the fall of 1420 , the party of law and order took speedy and effective measures to suppress social and theological extremism and to transform the city,

${ }^{37}$ Isaac de Beausobre, Rozprava o ceských Adamitech, trans and ed by Amedeo Molnár (Prague CSAV, 1954), Ernst Werner, "Die Nachrichten uber die bohmischen 'Adamiten" in religionshistorischer Sicht," in Circumcellionen und Adamiten, by $T$ Buttner and $E$ Werner (Berlın Akademie-Verlag, 1959), pp 73-141

${ }^{38}$ Kaminsky, "The Religion of Hussite Tabor" (cited in note 36), p 213

${ }^{39}$ Ibıd , p 217 (quotation from a Czech tractate by Príbram)

${ }^{40}$ lbid (Kamınsky's interpretation) On the medieval tradition of primitivism, see George Boas, Essai's on Primitivism and Related Ideas in the Middle Ages (New York Octagon Books, 1966) and Gordon Leff, "The Makıng of the Myth of a True Church in the Later Middle Ages," Journal of Medieval and Renassance Siudies, 1 (1971), pp 1-15 
and the whole Taborite coalition of similar brotherhoods, into a formidable military alliance. In cooperation with the Praguers and other moderate streams of Hussitism, the Taborites successfully repulsed all crusades mobilized against the Bohemian heretıcs (1420-1431)

Their theologians, partıcularly Bishop Nicholas of Pelhřımov, played a decisive role in the negotiations for the greatest theological triumph of the Hussite Reformation the agreement between the unconquered Hussites and the official delegates of the Council of Basel, known as the Iudex compactatus in Egra (The Judge of Cheb, signed in the Bohemian city of Cheb on May 18, 1432). The agreement elevated the Bible above any other ecclesiastical authority and thus enunciated the so-called formal principle of the sixteenth-century Reformation, sola Scriptura 41

The ecclesiological patttern which emerged among the Taborites during this third and final phase was an unusual model of restorationism. It was thoroughly biblical in that it sought to mould all aspects of life by the norm of the Scriptures. But the hermeneutical focus was enlarged from the earlier preoccupation with the Sermon on the Mount and the recorded practices of the Apostolic Church to the Scriptures as a whole.

The issue of war and peace can serve as a good example of this shift in hermeneutical approach. In its first stage, the Hussite radicalism was pacifistic. During the second stage, the chiliastic enthusiasts did not hesitate to incorporate into their apocalyptic vision the idea of a holy war of annihilation of the ungodly. In the final phase, the Taborite theologians cooperated with the University masters in Prague in formulatıng a revised theory of the just war. At the same tıme, the Taborite military bands launched raids into neighboring countries with the avowed purpose of propagating the Hussite program of reform (the Taborite Manifestoes) ${ }^{42}$ These raids expressed the spirit of a holy war no less than the invasions of Bohemia by the Catholic crusaders.

On the home front, the Taborites established a new ecclesiastical and political order In the fall of 1420 , they elected Nicholas of Pelhrimov as bishop or senıor. He had earned a bachelor's degree in arts and received priestly ordination in 1414 . His episcopal task was described in a contemporary chronicle as follows:

\begin{abstract}
All their priests were to be guided by him, nor might any preach the word of God to the people unless with the consent of this bishop Furthermore he, together with the other priests, was to dispense the funds of the community, faithfully, according to what he deemed to be the need of each of the brethren 43
\end{abstract}

The chronicle also records the reinstatement of rents payable by the peasants to their lords, including the city of Tabor. The egalitarian vision of a new social order proclaimed by the Taborite priests only a few months earher was discarded in favor of the old feudal system.

4'The Cheb Judge stated "Item in causa quattuor articulorum, quam ut praefertur prosequuntur, lex divına, praxıs Chrıstı, apostolıca et ecclesıae prımıtıvae, una cum doctoribus fundantıbus se veraciter in eadem, pro veracissimo et evidentı ıudice in hoc Basilıensı concilıo admıttentur" Frantıšek Palacký, Urkundlıche Bettrage zur Geschichıe des Hussıtenkrieges, 2 (Prague, 1873), p 282 Cf Zeman, Central European History (note 33), pp 133-34

42Bartos, Husıstvi a cızına (note 20), pp 217-32

${ }^{43}$ Laurence of Březovà, "The Hussite Chronicle," ed J Goll, Fontes rerum Bohemicarum, 5 (Prague, 1893), p 438 Englısh trans by Kaminsky, A Hisiory of the Hussıe Revolution, pp 385 86 
When one seeks to relate the Taborite model of church and society in its final stage $(1420-1436)^{44}$ to patterns of Christian restitutionism in history, the ambiguities of the situation rase basic doubts about the justification of such classification

On the one hand, the Taborite Church was demonstably separate from both the Catholic and Utraquist herarchical control and orders of ministry. It developed a distunct liturgy and theology. One might claim that the Primitive Church remained their model.

On the other hand, their identification of church and civic community and the consistent subjection of both to the Law of God would suggest the stance of "theocratic transformationism," as expressed much later in Calvin's Geneva, in the Puritan Commonwealth under Cromwell, and in New England, rather than the normative pattern of separatist restitutionism exemplified, among others, by the Evangelical Anabaptists. ${ }^{45}$

In terms of ideological roots, the Taborite system represents a unique synthesis, "a coalescence of the Waldensian sectarian negation with the Wycliffite positive program of realistic reform of social order." 46

The shortcomings and inconsistencies of the Taborite theocratic commonwealth were exposed by the most original Hussite thınker, Peter Chelcický.

\section{ChelcickÝ, The Prophet of Radical Separatism}

A lay theologıan, with only limited knowledge of Latin, Peter Chelčıcký (c. 1380-c. 1460) entered into a personal and hterary dialogue with leaders of all Hussite parties. The ideological tensions and agonies of his turbulent age are reflected as though in a polished mirror in his fifty-six preserved writıngs (all of them in (zech). They constitute one of the best sources for a historian of ideas who seeks to disentangle the maze of currents and undercurrents in Hussite Bohemia. Chelčický was not a "joiner," nor an organizer. ${ }^{47} \mathrm{He}$ did not directly initiate a fellowship of followers although he is usually regarded as the "spiritual father" of the Bohemian Brethren, Unitas Fratrum. He was a keen observer and an outspoken critic.

Above all, he succeeded in drawing together the many threads of late medieval dissent and weave them into a new, original pattern. In retrospect, he may well be called the forgotten prophet of separatism and restitutionısm, the theologian of the Radical Reformation. Within the limited scope of this essay, we shall underline five central emphases in his thought. ${ }^{48}$

${ }^{44}$ After the defeat of the Taborite armies in the fratricidal battle at Lipany in 1434, the city of Tabor retained its unique ecclesiastical order under the leadership of Bishop Nicholas of Pelhfimov until 1452 when it was forced to surrender to King George and conform to the order and doctrines of the Utraquist Church

${ }^{45} \mathrm{Cf}$ the application of the typology proposed by $\mathrm{H}$ Richard Niebuhr in his Christ and Culture (New York Harper \& Row, 1941) in the book Protestant Concepts of Church and State by Thomas G Sanders (New York Holt, Rinehart \& Winston, 1964)

"Nechutová, Misıo Mikulásé, p 71 Cf Kamınsky, "Wycliffism as Ideology of Revolution" (cited in note 23), pp 68ff

${ }^{47}$ Matthew Spınka, "Peter Chelčcky the Spıritual Father of the Unitas Fratrum," Church History 12 (1943), p 281

${ }^{\star *}$ The best study of Chelčıcky' in Englısh is "The Life and Thought of Petr Chelčıký A Radical Separatist in Hussite Bohemia," Murray L Wagner (Th D thesis. Chicago Theological 
1 In spite of his lack of formal education, he was reasonably familiar with the Wycliffite, Waldensian and Hussite ideas as well as with the writıngs of patristic and scholastic authors available in Bohemia in his day. He subjected all of them to the scrutiny of the Scriptures. In his approach to the Bible he went beyond the moralizing Hussite concept of lex divina and paid balanced attention to the whole canon of Scriptures (as evidenced in his large Postil, c. 1435). Nevertheless, the witness of Christ, and particularly the Sermon on the Mount, retained for him the supreme normative value.

2. The christocentric focus is expressed in his theology of the cross. The gospel is both an offer of the benefits derived from Christ's suffering, and a summons to take up the cross and follow him. The Christian way is the way of the cross, the path of non-resistance and non-violence. Christians who are not willing to suffer are not true disciples. ${ }^{49}$ Nor can a Christian legitimize any coercion in religion. Chelčický had seriously considered the arguments for a just war advanced by the University masters and the Taborite priests but he remained a consistent pacifist (On Spirttual Warfare, c. 1421) through the long years of bloodshed in Hussite Bohemia.

\begin{abstract}
It seemed to John Hus as though Christians were not henceforth obliged to follow the apostles and the Holy Primitive Church in suffering, because now kings have entered the church But the Primitive Church followed the apostles for three hundred and twenty years in suffering and in great tribulations among the pagans, not using secular power but suffering the pagan powers - up to Constantine. And when he, after many cruelties, wanted to glonfy himself in Christ, he pushed himself into the Christıan community along with his pagan lordship. And the poor priest [Sylvester] who had hid before him in caves and forests recelved honor and imperial lordship from him and thus fell away from the faith. Hence when this evil came to pass, a voice was heard saying, "Today poison has been poured into the Holy Church" - as though the fatth were to cease on account of these two rich lords, the secular and the spiritual, and as though suffering would be elıminated Then the doctors set about to serve the secular lords by collecting texts from the Old and New Testaments, to set the lord and his sword securely under Chrıst's faith, as the apostle and vicar of divınity ... so
\end{abstract}

3. The preceding quotation (from Chelcicky's Reply to Rokycana, c. 1435) suggests a clear vision of the Church restored to its pre-Constantinian powerlessness and separateness from the wealth and prestige of the world. The symbiosis between church and society, initiated in the fourth century, has been the

Semınary, 1973; to be published) See also Peter Brock, The Pollitical and Social Doctrines of the Unity of Czech Brethren in the Fifteenth and Early Sixteenth Centuries (The Hague Mouton, 1957), pp 25-69, H. Kaminsky, "Peter Chelcicky's Place on the Hussite Left," Introduction to "Peter Chelcický. Treatıses on Christianity and Social Order," Studies in Medieval and Renatssance History, 1, ed W Bowsky (Lincoln, Nebraska, 1964), pp 107-36 Kaminsky's work includes Englısh trans of Chelčcký's tracts "On the Triple Division of Society" and "On the Holy Church " Part 1 of his "Net of Fath" was translated by Ennico C. S Molnár as part of an unpublished B.D thesis (Pacific School of Religion, Berkeley, California, 1947)

${ }^{49} \mathrm{Cf}$ Chelčcky's rebuke to the priest Martın Húska in Tabor (1420/21) "But Martın was not humble or at all willing to suffer for Christ - even as you are not. And he declared to us his belief that there will be a new Kingdom of Saints on earth, and the good will no longer suffer, and he said, 'If Christians were always to have to suffer so, I would not want to be a servant of God ' That is what he said'" (Trans. by Kaminsky in Church History 26 (1957), p. 59.

${ }^{\text {so }}$ Trans by Kaminsky in his History of the Hussite Revolution, pp 391-92. 
main cause of apostate Christıanity. Chelčıký rejects in princıple the medieval parish system with its economic exploitation of the common people through the collection of tithes and other fees. ${ }^{51}$ In its place, he advocates free itınerant preaching of the Word. It appears that Chelčický, like the Waldensians up to his tıme, did not propose an alternate network of separatist congregations.

4. Chelčcký also followed the Waldensıan view of history. The fall of the Church occurred when "two monstrous whales," namely Emperor Constantıne and Pope Sylvester, entered the net of the Church and "tore it to such an extent that very little of it has remained whole" (The Net of Faith, c. 1440). ${ }^{52}$ As a prophet of the Free Church Movement, Chelcický renounced the Wycliffite and Hussite Magisterial Reformation.

5. In disagreement with Wyclif, Hus and the entire scholastic tradition, Chelcický condemned the feudal division of society into three classes: the nobility, clergy and common people (On the Triple Division of Society, c. 1425). Christians are equal brothers and the class structures have no place among them. Chelčcky's vision of a "classless society" includes the abolition of serfdom, and the demand that all men, including the priests, support themselves through work.

Chelcicky's egalitarian vision should not be interpreted as a blueprint for the society as a whole but rather as a life style for a mınority within society, namely the genuine Christians. They cannot serve as secular magistrates, nor should they exploit others economically. The society at large, outside the community of commited Christians, cannot be expected to follow in the footsteps of the Servant Christ

Chelčický was neither anarchist nor utopian. As a radical separatist he drew a clear line of distinction between the true Church and a nominally Christian society He sought to expose the sham of the latter. “. . . we must see Chelčıcký as the first genuıne revolutionary ideologist. For he alone separated the secular from the sacred, and set each adrift, to find its own future." $\$ 3$

\section{UNITAS FRATRUM}

Chelcický's vision of radical separatism and primitivism became a reality when in 1457, at the end of his life, a small group of earnest seekers, led by Gregory of Prague, left the Utraquist Church and established a religious community at Kunvald in Eastern Bohemia. They called themselves simply Brethren (fratres legis Christi) Their opponents, as well as some of their friends in other countries usually referred to them as the Pikarts, or the Waldensians, or the Waldensian Brethren (fratres Valdenses). Eventually, the official name was Unity of Brethren (Unitas Fratrum). ${ }^{54}$

There were a number of reasons for their separation from the national Hussite Church. Foremost in their minds was the soteriological concern (nouze spaseni, Hellsnot). They asked: Where and how can we find full assurance of salvation?

\footnotetext{
"See the well-documented study by Amedeo Molnár, "Crisis of the Parish," Communio Vlatorum, 13 (Prague, 1970), pp 45-56, esp pp 50ff

S2Trans by Spınka, "Peter Chelčıký," p 289

${ }^{53}$ Kamınsky. "Peter Chelčcký Treatıses" (cited in note 48), p 131

54There is no critical history of the ancient Unitas Fratrum in English For the earliest phase, see Brock, The Political and Social Doctrines The two standard works in German are Josef Th Muller, Geschichte der bohmischen Bruder, (3 vols, Herrnhut 1922-1931) and Rudolf Ričan, Die Bohmischen Bruder, ihr Ursprung und ihre Geschichte (Berlin Union Verlag, 1961)
} 
Their answer was not as simple as the question. It included a semi-Donatist search for "good priests" whose moral character would not hinder the flow of grace; a desire to hear the Word of God proclaımed in purity; a Waldensian rejection of the marks of fallen Christendom: war, magisterial power and oathtaking; avoidance of vocations such as commerce, which in their mind were a hindrance to consistent discipleship (vocatıonal primitivism); and a longing for a supportive fellowship in love. 55

In 1467 , they chose (by lot) and ordained their own ministers independent of the apostolic succession in the Roman Church. Subsequent misgivings about the legitımacy of their decision led them to seek a confirmation of their new ministers by a Waldensian elder. They appear to have accepted the legend about Peter Valdes as a contemporary of Pope Sylvester and mediator of the uncorrupt line of successıon from the primitive Church (a kind of sectarian "counter-succession"). ${ }^{56}$

The hesitation with which they established their own ministry, and the retention, until 1528 , of all seven sacraments - albeit with new meaning and intent - does not measure up to the unequivocal acts of separation in later times (German and Swiss Anabaptism, and English Congregationalism). But there is a right time (kairos) for every new idea to find acceptance. The Unity was born prematurely, in the context of the late medieval unitary Christian society unprepared for religious dualism, let alone pluralism.

But there can be no doubt about the genuine ecclesiastical separatism of the early Brethren. They established a network of congregations totally independent of the Utraquist and Catholic parishes. They had their own ministry, sacraments and discipline. There were strict rules for admission into membership.

The first, preparatory stage of training and testing was patterned after the catechumenate in the Ancient Church. Upon its completıon, candidates with Catholic or Utraquist background joined the Unity through believer's baptism (rebaptism). Children born to members of the Unity were baptized as infants (with a different meaning to the sacrament) and after training, joined the Unity through the act of confirmation. Provision was made for further training and growth of members. Church membership was understood as a life-long process of spiritual formation marked by the three levels of membership: incipientes, progredientes, perfecti.

In the history of restitutionism, Unitas Fratrum must rightfully be designated as the first believers' church and the first free church. The first generation of the Brethren exemplified both ecclesiastical and societal separatism. The numerical growth of the Unity and its appeal to seekers among the wealthier and more educated strata of Bohemian society precipitated a crisis in the 1490 s. Following a division, the Minor Party adhered to the original principles of strict social isolationism. The Major Party, led largely by new converts to the Unity from Utraquism, made significant adjustments in its societal separatism while fully retaining the high standards of ecclesiological separatism.

The new provisions allowed burghers, members of the noblity and persons with university education to join the Unity. Members were now allowed to

${ }^{35} \mathrm{Cf} \mathrm{F} \mathrm{H}$ Littell's characteristic of the Unitas Fratrum in his essay, "The Concept of the Believers' Church," The Concept of the Believers' Church, ed James Leo Garrett, Jr (Scottdale, Pa Herald Press, 1969), pp 22-23 See also Durnbaugh, The Believers' Church, pp 57ff

st The sources are ambiguous and allow for several interpretations of the reasons for the Waldensian confirmation of the newly elected mınısters Cf Molnár, Valdensti, pp 229-30 
participate in civic government and to take oaths. Pacifism was still upheld as the ideal but was no longer demanded. On the whole, the relaxed rules reflected the increasing urbanization of the Unity. The change did not represent a reversal of the former attitudes but merely a cautious reinterpretation of societal separatism. ${ }^{\text {s? }}$

In Luke of Prague (d. 1528), the leader of the new generation, the Unity reached the peak of its creative period. In more than one hundred fifty Czech writings, Luke developed a complete theological system ${ }^{58}$ An evaluation of its structure and significance goes beyond the purpose of this essay. However, a brief reference to Luke's ecclesiology must be included here.

Luke utilized the traditional scholastic categories of substantialia, ministerialia et accidentialia in a soteriological perspective, and classified all matters of Christian faith and practice under the trichotomy: things essential unto salvation, 59 things which minister unto salvation (the Word, sacraments, discipline and the Church as such), and things incidental (liturgy and church government). The implied hierarchy of values assigned to the respective concerns in Christian life has, in our opinion, important bearing upon a theology of free church restitutionism.

Under Luke's leadershıp, the Brethren used three distinct terms to describe the reality of the Church. The word Church (ecclesia, cirkev, Kirche) was reserved for the Universal Church. Each denominational part or unit was described as Unity (unttas, jednota, Unität), e.g. the Roman or Utraquist Unity. Each local congregation of the Unitas Fratrum was zbor (Gemeinde). The term was never applied to the Catholic or Utraquist parish churches (kostel, farnost).

The consistent use of this terminology served as a reminder of the dialectical tension between the ecumenical and separatist motifs in their ecclesiology. Much of Luke's theological work was expended on clarification of reasons for the separation of the Unity. At the same time, the Brethren never grew weary of seeking contacts and dialogue with all streams of the Universal Church, particularly after the rise of the Protestant Reformation. ${ }^{60}$

\section{Conclusion}

A study of the late medieval renewal movements would be incomplete without a few concluding remarks on the nature and typology of late medieval dissent.

The typological categories proposed by Troeltsch, Littell, Williams,

${ }^{57}$ We disagree with the interpretation offered by Brock, The Political and Social Doctrines, pp 206ff, according to which the relaxed rules meant a complete break with the separatist standards of the Old Brethren. Of the discussion in Zeman, The Anabaptists and the Czech Brethren,p 202, and Molnár's critıcısm of Brock's thesıs in Krest'anská revue 24 (1957), pp. $217-$ 18

ssAmedeo Molnár, Bratr Lukás, bohoslovec Jednoty (Prague, 1948) and the histories by Muller and Rixan (cited in note 54)

${ }^{59}$ According to Luke, things essential unto salvation are (1) "on God's side" - the grace of God the Father, the merit of Jesus Christ and the gifts of the Holy Spirit, (2) "on man's side" - faith, love and hope.

${ }^{60} \mathrm{~F}$ Bednáf, "The Ecumenical Idea in the Czech Reformation," The Ecumenical Review 6 (1954), pp 160-68, F M Dobiás, "Ecumenical Motifs in the Theology of the Unity of Bohemian Brethren," The Ecumenical Review' 12 (1960), pp 455-70; Amedeo Molnár, "Der okumenısche Gedanke im tschechischen Protestantısmus," Communıo Viatorum 7 (1964), pp 7-15 
Durnbaugh and Yoder, ${ }^{61}$ could be applied to the Waldensian, Wycliffite and Hussite Movements. However, we shall follow a different approach in our brief summary.

Late medieval dissent was basically a response to the threefold crisis in church and society during the fourteenth and fifteenth centuries: a crisis of authority, a crisis of morality and a crisis of spirituality.

1. Since medieval "Christian society" (corpus Christianum) was built on the principle of hierarchical authority, both ecclesiastical and political, the mounting criticism and undermining of that authority constituted the fundamental cause of the crisis of the Middle Ages.

During the period studied in this essay, the authority of the Pope was undermined sımultaneously by the shock of the Schism, by 1deological critique such as occamism and wycliffism, and by the theories and temporary triumphs of conciliarism. The attacks against papacy were matched by condemnation of the moral decay and economic oppression among the lower and higher clergy at the parochial and diocesan levels. Thus the entire authoritarian system of the Church, in its governıng as well as sacramental aspects, was being called into question.

At the same time, the "universal" authority of the Empire was challenged by forces of nationalism. The feudal class system was being weakened by general social unrest related to the growth of urban population, and its proletariat, and to the transition from agrarian to capitalistic economy.

The response by the late medieval reformers to this complex crisis of authority was twofold. In the first place, the Bible became the supreme criterion of truth. The authority of the Pope, Church councils and tradition, when recognized at all, was made subject to scriptural authority. The pleas for the return to the Primitive Church meant, in practice, a return to its model described in the New Testament.

The second response to the crisis of hierarchical authority consisted in a gradual, or at times revolutionary transfer of power, in church and society, from clerical control into the hands of the laity. It is important to note that Wyclif's theology of the magisterial control of Church contributed as much to this trend as the Lollard and Waldensian call for lay preaching. In Bohemia, the Hussite King George of Podebrady furthered the development of a lay state, fully independent from any church domination. He also envisaged and promoted a lay-dominated European state system. ${ }^{62}$ The minimization of the differences between clergy and laity - implied, for example, in the Hussite restoration of the chalice to lay people - furthered an egalitarian democratic trend.

2. In the minds of many late medieval dissenters, the grave crisis of morality was linked directly with the accumulated wealth of the Church. ${ }^{63}$ The beginning of the decay was traced back to the era of Emperor Constantine and his bestowal of privileges upon the Church (The Donation of Constantine).

${ }^{61}$ Troeltsch, The Social Teachings of the Christıan Churches, vol. 2, pp 993ff, Franklin H Littell, The Free Church (Boston Starr King Press, 1957), pp 26ff , and his important typological study The Origins of Seciarian Protestantism (New York Macmillan, 1964); George H Willams, The Radical Reformanion (Philadelphia The Westminster Press, 1962), pp 853ff, Durnbaugh, The Believers' Church, pp $30 \mathrm{ff}$, John Howard Yoder in James Leo Garrett, The Concept of the Believers' Church, pp 254ff

${ }^{62} \mathrm{~F}$ Kavka et al (ed ), The Universal Peace Organization of King George of Bohemia (Prague CSAV and UNESCO, 1964)

${ }^{63}$ In pre-Hussite Bohemia, more than half of the land was owned by the Church and religious orders 
The main remedy prescribed by the dissenting leaders was the return of the Church, and particularly of the clergy, to primitive Christian poverty. The Wycliffite and Utraquist leaders advocated "coercive primitivism": the Church should be restored to poverty through confiscation of its property by secular authorities.64 The Waldensians and the Bohemian Brethren represented "voluntary primitivism" in the Franciscan tradition: individual Christians were called upon to choose poverty as one of the marks of Christian discipleship.

3. The crisis of spirituality affected all aspects of piety by which late medieval men sought an assurance of salvation. The crisis meant a critical questioning of the benefits promised through the sacraments, pilgrimages, indulgences and other means.

The response of the dissenters varied considerably. Some of them, like the preHussite Reformers and the Utraquists, urged frequent communion while others, like the spiritualists among the early Taborites, rejected sacramental means altogether. The Waldensians, Chelcický and the original Bohemian Brethren chose the path of Christ-like self-denial, "the way of the Cross." Combined with vocational primitivism, it led to separation from the mainstream of society. Still others dispaired of any hope for renewal of the present order and eagerly anticipated an apocalyptic intervention by God.

All three dimensions of the crisis - authority, morality and spirituality - were reflected in the quest for the true Church of Christ. That is why the concept of the Church became the central point in the late medieval renewal movements.

Perhaps the most fascinating aspect of this search for the true Church - and for an authentic Christian faith - was the dialectic tension between the reformist and the restitutionist streams of late medieval dissent. One cannot understand either stream without an appreciation of the reciprocity between them. At times, the two currents merged, as in Taborite theocratic primitivism.

The reformist thrust was expressed in the ideology of Wyclif, the precursors of Hus and the moderate Utraquists. In spite of many differences in particular doctrines, all these Reformers accepted the post-Constantinian concept of a Christian society, and did not question the cooperation between church and state, nor the symbiosis of religion and culture.

A sense of historical continuity and tradition led them to gradualism in reform. They never gave up the medieval vision of the One Church even though its universality came to be understood in terms of national or territorial religious uniformity.

Their program of reform was inspired primarily by the Bible and the example of the Early Church. In that sense, their vision belongs to the tradition of primitivism. However, they sought to implement reforms not only through preaching and individual response to it but also through legal, and at times coercive measures (theocratic reformism, coercive primitivism). In many respects they anticipated the Magisterial Reformation of the sixteenth century.

The restitutionist stream of the late medieval dissent, represented in our study

${ }^{64}$ The official Hussite program, "The Four Articles of Prague" (1420) demanded in its third article that priests and monks be coerced to live in apostolic poverty, "according to the Holy Scripture, following the way of Christ and the apostles." See Otakar Odlożilik, The Hussite King (New Brunswick: Rutgers University Press, 1965), p 5, and Zeman, Central European Historv, pp $132 \mathrm{ff}$ 
by the Waldensians, the early Taborites, Chelcický and the Bohemian Brethren, rejected the Constantınian pattern as a betrayal of primitive Christianity. In place of an unitary view of history and society, the restitutionists recaptured a sense of tension between the Church and the world, as they found it expressed in the New Testament. This fundamental dualism - which should not be confused with the metaphysical dualism of the Albigenses ${ }^{65}$ - made it easier for them to suggest the formation of groups separated from the Catholic Church.

The fall of the Church under Constantine became the turning point in the history of Christianity. The return to pre-Constantınian Christianity implied contempt for all external security for the Church, particularly when it was bestowed by the state. A strong eschatological awareness of many restitutionists furnished a second anchor for their view of Christian destiny. As God's pilgrim people (communio viatorum) they looked back to the Primitive Church but they also anticipated Christ's consummation of history. Both perspectives, the primitivist and the futuristic, effectively weakened any remaining attachment to the present world order.

It is not surprising, therefore, that the original mode of restitutionist separatism was at once ecclesiastical and societal. The relative emphasis on the one or the other varied from group to group, and sometımes changed within the same group, as for example, during the transition from the first to the second generation in the Unitas Fratrum. In the subsequent development of the restitutionist movement, in Europe, in England and in America, the two aspects of separatism did not always go hand in hand.

Perhaps the most important question which the legacy of the late medieval dissenters should raise in the minds of those who claim to represent the primitivist and restitutionist tradition in America today, is: can a genuine restitution of Primitive Christianity be limited to doctrines and forms of church life (ecclesiastical separatism) without a costly dissent from the values and life style of our fallen society (societal separatism)?66

${ }^{65}$ On the interaction between the early Waldensians and the Albigenses (Cathars) in France, see Molnár, Valdenší, pp $24 f f$

${ }^{66} \mathrm{Cf}$ the statement by George Willams "A complete ecclesiology or theology of the Believers' Church must take seriously not only the matrix out of which it originally emerged, but also the cultural "corpus christianum" that it subsequently forms about itself in the process of biological growth, cultural accomplishment, and social accommodation" (James Leo Garrett, The Concept of the Believers' Church, p 101) 
THE RESPONSIBLE GOD:

A STUDY OF THE CHRISTIAN PHILOSOPHY OF H. RICHARD NIEBLHR

DONALD F. FAD VER

Price: $\$ 4.20(\$ 3.00$ to members)

THREE USES OF CHRISTIAN DISCOURSE IN JOHN HENRY NEWMAN

JOLETT L. POWELI.

Price: $\$ 4.20$ ( $\$ 3.00$ to members)

THE RELIGIOUS LANGUAGE OF NICHOLAS OF CUSA JAMES E. BIECHLER

Price: $\$ 4.20$ (\$3.00 to members)

THE HERMENEUTIC OF DOGMA

THOMAS B. OMMEN

Price: $\$ 4.20$ (\$3.00 to members)

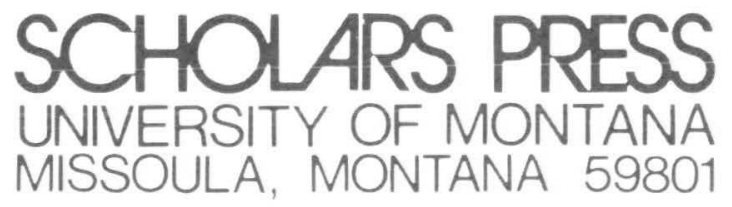

